\title{
前立腺全摘除術後の膀朕・尿道機能の経時的変化の検討
}

\author{
東京医科菌科大学医学部泌尿器科学教室（主任：大島博幸教授） \\ 安藤 正夫* 永松 秀樹 森田 隆 \\ 石丸 尚** 福井巌\# 大島 博幸
}

\section{CONSECUTIVE EVALUATION OF VESICO-URETHRAL FUNCTION IN PATIENTS UNDERGOING RADICAL RETROPUBIC PROSTATECTOMY}

\author{
Masao Ando, Hideki Nagamatsu, Takashi Morita, Hisashi Ishimaru, \\ Iwao Fukui and Hiroyuki Oshima \\ Department of Urology, Tokyo Medical and Dental University, Faculty of Medicine \\ (Director: Prof. H. Oshima)
}

We evaluated vesico-urethral function after radical retropubic prostatectomy in 18 male patients by consecutive urodynamic studies. At the time of the operation average age was 68 years with a range between 56 to 78 years old. The follow-up period after the operation was over 12 months in all patients. Pathological stage was T1 in 2, T2 in 6, T3 in 8 and T4 in 2 patients. Urodynamic evaluation including uroflowmetry, cystometry, urethral pressure profilometry (UPP) and external anal or urethral sphincter electromyography was performed before and 1, 3,6 and 12 months after the operation. The status of postoperative urinary incontinence was reported by the patients.

Sixty-five per cent of the patients revealed the low compliance bladder less than $10 \mathrm{ml} / \mathrm{cm}$ water at one month after the operation, however, most patients had normal vesical compliance and normal cystometrogram at 12 months. Both functional profile length (FPL) and maximum urethral closure pressure (UCPmax) in UPP were markedly lowered immediately after the operation and both indexes were significantly lower even at one year after the operation than preoperative ones.

Both the incidence and the degree of incontinence improved during postoperative 12 months; complete urinary control was achieved in 11 patients $(61 \%)$, stress urinary incontinence was present in 6 patients $(33 \%)$ and one patient $(6 \%)$ was still totally incontinent. Shortening FPL was considered to be the risk factor on postoperative urinary incontinence. Resection of bilateral neurovascular bundles and lower UCPmax seemed to have the possibility of the influence on it. Low compliance bladder is also likely to be one of the factors to cause early postoperative incontinence.

Key words: radical prostatectomy, urodynamic study, urinary incontinence

要旨：前立腺癌に対する根治的前立腺全摘除術後の膀胱・尿道機能を経時的に検索し, 術後の尿失禁に 関与する因子を解析した。

対象は恥骨後式前立腺全摘除術後 12 カ月以上経過した前立腺癌 18 症例である. 手術時年齢は $56 \sim 78$ (平 均68）歳で, 病理学的病期は $\mathrm{pT}_{1} 2$ 例, $\mathrm{pT}_{2} 6$ 例, $\mathrm{pT}_{3} 8$ 例, $\mathrm{pT}_{4} 2$ 例である。術前および術後 $1 ・ 3 ・$ 6 ・12 カ月に尿流測定 (UFM), 膀胱内圧測定 (CM), 尿道内圧測定（UPP）などの尿流動態検查を施

行し, 尿失禁の評価は問診で行った。

術後早期には $65 \%$ の例で $10 \mathrm{ml} / \mathrm{cmH}_{2} \mathrm{O}$ 未満と極めて低い膀胱コンプライアンスを呈したが, 大部分の 例では経時的にコンプライアンスは増大し CM 曲線も正常化した. UPPにおける機能的尿道長 (FPL),

\footnotetext{
* : 現在, 東部地域病院泌尿器科

**: 現在, 土浦協同病院泌尿器科

\#：現在, 癌研究会附属病院泌尿器科
} 
最高尿道閉鎖圧 $(U C P \max )$ とも術後早期には著明に低下し，術後12カ月でも術前より有意に低值であっ た.

術後の尿失禁は頻度・程度とも経時的に改善し，術後12 カ月では尿禁制11例 (61\%), 腹圧性尿失禁 6 例 $(33 \%)$ ，完全尿失禁 1 例（6％）となった。術後尿失禁の危険因子としてはFPLの短縮が想定され たが, 神経血管束の両側切断や UCPmax の低下が尿失禁に関与している可能性も示唆された。 た。, 術 後早期には膀胱コンプライアンスの低下も尿失禁に関与するものと想定された. キーワード：根治的前立腺全摘除術, 尿流動態検査, 尿失禁

\section{緒言}

早期前立腺癌に対して行われる根治的前立腺全摘除 術の術後合併症としては, インポテンスや尿失禁, 膀 胱尿道吻合部狭窄などが報告されている11 3). 今回, 術 後 12 力月上経過した症例を対象として, 膀胱・尿道 機能の変化を経時的に検討し, 術後の尿失禁に関与す る因子の解析を試みたので報告する。

\section{対象および方法}

1986年 5 月から1993年 3 月までに当科では27例の前 立腺癌症例に対して恥骨後式根治的前立腺全摘除術を 施行した。このうち，術後 12 カ月以上経過した症例は 23例であるが，Lapides 膀胼瘻の 2 例と他院に転院し た 1 例および手術前後での尿流動態検査が不十分な 2 例の計 5 例を除いた 18 例を解析対象とした。手術時年 齢は56 78歳 (平均68歳)である。臨床病期は $\mathrm{A}_{2} 3$ 例, $\mathrm{B}_{1} 2$ 例， $\mathrm{B}_{2} 9$ 例，C 4 例であったが，病理学的病期は $\mathrm{pT}_{1} 2$ 例, $\mathrm{pT}_{2} 6$ 例, $\mathrm{pT}_{3} 8$ 例, $\mathrm{pT}_{4} 2$ 例 ( 2 例とも膀 脱後壁への浸潤), $\mathrm{pN}_{0} 12$ 例, $\mathrm{pN}_{1} 5$ 例, $\mathrm{pN}_{2} 1$ 例であっ た。臨床病期 $A_{2}, B_{2}$ の各 1 例では両側神経血管束を温 存し， $\mathrm{B}_{1} 2$ 例および C 1 例の計 3 例は片側神経血管束 を温存したが, 他の13例は両側神経血管束を切断した。 また，片側神経血管束を温存した C の 1 例は膀胱三角 部および後壁の瘢痕化が強く，三角部片側を切除せざ るを得なかった。膀胱尿道吻合方法は, 結節縫合 1 例, マットレス縫合 14 例, 両者の併用 3 例で, 全例膀胱頸 部を縫縮した。なお，尿道造影で吻合部からの造影剂 の溢流がなければ術後 2 週目に尿道留置バルーンカ テーテルを抜去した。

膀胱・尿道機能の評価は，既報 ${ }^{2}$ と同様に手術前およ び術後 1 力月， 3 力月， 6 力月， 12 力月に尿流動態検 査として尿流測定(以下 UFM と略)，炭酸ガス膀胱内 圧測定 (以下 $\mathrm{CM}$ 之略), 外尿道 (肛門) 括約筋筋電図 (以下括約筋 $\mathrm{EMG}$ と略), 尿道内圧測定 (以下 UPP と 略) を行い，気体膀胼撮影，逆行性尿道造影，排尿時 膀胱尿道造影を適宜行った。尿流動態検査は, DISA 21 G01型およびDANTEC UD5500型ウロダイナミック
システムを使用して行った． CM は盲端となった先端 から $4 \mathrm{~cm}$ の部位にそれぞれ直角に直径 $1 \mathrm{~mm}$ の 4 孔の ある $10 \mathrm{~F}$ シリコンカテーテルを尿道より挿入し， 1 分 間に $100 \mathrm{ml}$ の炭酸ガスを注入して測定した。括約筋 EMG は，肛門括約筋の場合は肛門周囲 3 時と 9 時の 部に白金表面電極を貼布し，外尿道括約筋の場合は同 心針電極を刺入して導出し CM と同時記録した. UPP は同じカテーテルを使用し CM に引き続き膀脂を空 にした後, 炭酸ガス流量 $50 \mathrm{ml} / \mathrm{min}$, 自動牽引速度 0.5 1.0 mm/ sec で行った. また, UFM で最大尿流率 (以下 $\mathrm{Qmax}$ と略) が $7 \mathrm{ml} / \mathrm{sec}$ 未満で尿流曲線パター ンが平坦型を呈し，かつ 7 号ネラトンカテーテルが挿 入不可能な場合を膀胱尿道吻合部狭窄と診断した ${ }^{3)}$. なお，膀胱・尿道機能に影響を及ぼす可能性のある薬 剤は，検査 2 日前より投与を中止した。

尿失禁の評価は問診で行い，尿失禁の程度は，尿失 禁はあるがパッド等は不要なものを軽度, パッド等が 必要だが 1 日 2 回以下の交換でよいものを中等度, パッド等の交換を 1 日 3 回以上必要とするものを高度 と規定した ${ }^{4}$. 有意差検定は $\chi^{2}$ 検定, $\mathrm{t}$ 検定およびウィ ルスコクソン $\mathrm{U}$ 検定で行った.

\section{結 果}

I. 膀胱・尿道機能の経時的変化

手術前後の UFM と残尿量の変化を表 1 に示した。 $\mathrm{Qmax}$ は術前 $15 \mathrm{ml} / \mathrm{sec}$ 未満の例が半数あり, 術後 1 力 月では $15 \mathrm{ml} / \mathrm{sec}$ 未満の症例の割合が高かった。術前は 三分の一の例が残尿量 $50 \mathrm{ml}$ 以上であったが, 術後は残 尿量が減少し術後 12 力では全例 $50 \mathrm{ml}$ 末満となった。 一方, UFM パターンは術前には器質的下部尿路通過 障害パターンを示す左山型(5)を呈する例が多く, 術後 1 力月の時点では平坦型りを呈する例が多かった。

CM における初期尿意量, 最大膀胱容量は術前後で 特徴的な变化は認められなかった。膀胱コンプライア ンスは成人の場合 $20 \mathrm{ml} / \mathrm{cmH}_{2} \mathrm{O}$ 以上が正常とされて いるが, $10 \mathrm{ml} / \mathrm{cmH}_{2} \mathrm{O}$ 未満とコンプライアンスが極め て低い例が術後 1 力月では全体の $65 \%$ を占めた。しか 
表 1 尿流測定 (UFM) - 残尿量の経時的変化

\begin{tabular}{l|c|c|c|c|c}
\hline \multirow{2}{*}{ UFM } & \multirow{2}{*}{$\begin{array}{c}\text { 術 前 } \\
(18)\end{array}$} & \multicolumn{3}{|c}{ 術 } \\
\cline { 3 - 6 } & & カ月 & $\begin{array}{c}3 \text { 力月 } \\
(14)\end{array}$ & $\begin{array}{c}6 \text { 力月 } \\
(16)\end{array}$ & $\begin{array}{c}12 \text { 力月 } \\
(17)\end{array}$ \\
\hline 最大尿流率 & & & & & \\
$15 \mathrm{ml} / \mathrm{sec}$ 未満 & 9 & 13 & 7 & 6 & 10 \\
$15 \mathrm{ml} / \mathrm{sec}$ 以上 & 9 & 3 & 7 & 10 & 7 \\
残尿量 & & & & & \\
$50 \mathrm{ml}$ 未満 & 12 & 14 & 13 & 15 & 17 \\
$50 \mathrm{ml}$ 以上 & 6 & 2 & 1 & 1 & 0 \\
パターン & & & & & \\
正常型 & 5 & 4 & 5 & 6 & 5 \\
左山型 & 10 & 4 & 5 & 4 & 7 \\
右山型 & 1 & 1 & 1 & 2 & 1 \\
平坦型 & 1 & 7 & 1 & 1 & 0 \\
波状型 & 1 & 0 & 2 & 3 & 4 \\
\hline
\end{tabular}

表 2 膀脱内圧曲線 (CMG) の経時的变化

\begin{tabular}{|c|c|c|c|c|c|}
\hline \multirow{2}{*}{ CMG } & \multirow{2}{*}{$\begin{array}{c}\text { 術 前 } \\
(18)\end{array}$} & \multicolumn{4}{|c|}{ 術 } \\
\hline & & $\begin{array}{c}1 \text { 力月 } \\
\text { (17) }\end{array}$ & $\begin{array}{c}3 \text { 力月 } \\
\text { (16) }\end{array}$ & $\begin{array}{c}6 \text { 力月 } \\
\text { (17) }\end{array}$ & $\begin{array}{c}12 \text { 力月 } \\
\text { (18) }\end{array}$ \\
\hline 初期尿意量 & & & & & \\
\hline $150 \mathrm{ml}$ 未満 & 15 & 14 & 10 & 12 & 13 \\
\hline $150 \mathrm{ml}$ 以上 & 3 & 3 & 6 & 5 & 5 \\
\hline 最大膀脱容量 & & & & & \\
\hline $300 \mathrm{ml}$ 未満 & 11 & 13 & 10 & 11 & 8 \\
\hline $300 \mathrm{ml}$ 以上 & 7 & 4 & 6 & 6 & 10 \\
\hline $\mathrm{C}\left(\mathrm{ml} / \mathrm{cmH}_{2} \mathrm{O}\right)$ & & & & & \\
\hline 10未満 & 0 & $11[65]$ & $4[26]$ & $4[24]$ & $1[6]$ \\
\hline $10 \sim 19$ & $6[33]$ & $4[23]$ & $6[37]$ & $7[41]$ & $4[22]$ \\
\hline 20 以上 & $12[67]$ & $2[12]$ & $6[37]$ & $6[35]$ & $13[72]$ \\
\hline パターン & & & & & \\
\hline 正常型 & 14 & 5 & 10 & 12 & 17 \\
\hline 過活動型 & 2 & 0 & 0 & 0 & 0 \\
\hline 低 C 型 & 0 & 11 & 5 & 3 & 0 \\
\hline 判定保留 & 2 & 1 & 1 & 2 & 1 \\
\hline
\end{tabular}

$\mathrm{C}$ ：膀胱コンプライアンス, ( ): 症例数, [ ] :\%

し経時的にコンプライアンスが正常化する症例の割合 が増加し, 術後 12 月では $72 \%$ の例が正常コンプライ アンスを呈した(表 2 )。図 1 に65歳・p $\mathrm{T}_{3} \mathrm{~N}_{1} \mathrm{M}_{0}$ 症例の $\mathrm{CM}$ の経時的变化を示すが, 術後 1 力月では最大静止 圧が高くそのまま排尿反射に移行するパターンを呈し ている，このパターンを呈するものを低コンプライア ンス型と定義すると,術後 1 力月では 17 例中 11 例, $65 \%$ の例がこのパターンを呈し, 経時的に正常型を呈する 症例が多くなることが判明した（表 2 ）.

括約筋 $\mathrm{EMG}$ は，排尿企図時あるいは排尿時に括約
図 1 前立腺全摘除術前後の膀腃内圧曲線の経時的推 移の典型例 $\left[65\right.$ 歳, $\mathrm{pT}_{3} \mathrm{~N}_{1} \mathrm{M}_{0}$ 症例, FDV : 初期尿意, $\mathrm{MDV}$ ：最大尿意, $\mathrm{VAC}$ ：排尿開始，（）は膀羘容 量了.

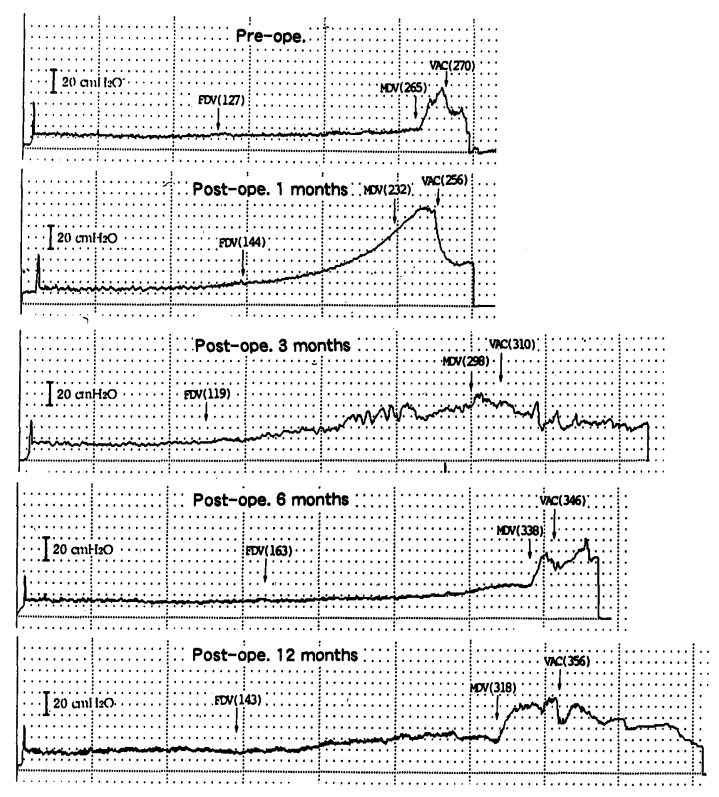

表 3 外括約筋筋電図 (EMG) の経時的変化

\begin{tabular}{|c|c|c|c|c|c|}
\hline \multirow{2}{*}{$\begin{array}{l}\text { EMG } \\
\text { パターン }\end{array}$} & \multirow{2}{*}{$\begin{array}{c}\text { 術 前 } \\
(18)\end{array}$} & \multicolumn{4}{|c|}{ 術 } \\
\hline & & 1 力月 & 3 力月 & 6 力月 & 12 力月 \\
\hline 正 常 型 & 15 & 7 & 9 & 14 & 10 \\
\hline 過 活 動 型 & 2 & 7 & 1 & 1 & 2 \\
\hline 判 定 保 留 & 1 & 2 & 1 & 0 & 0 \\
\hline
\end{tabular}

筋が十分に弛緩しない過活動型を呈する例が，術後 1 カ月では半数近くを占めたが，経時的に正常型を呈す る例が増えてくることが確認された（表 3 ）。

UPP に打ける機能的尿道長（以下 FPL と略）の手 術前後の変化を尿禁制群, 腹圧性尿失禁群, 完全尿失 禁群別に図 2 に示した。膀脱尿道吻合部狭窄により FPL および最高尿道閉鎖圧（以下 UCPmax と略）が 実際より高値に出る ${ }^{122}$ ため, 吻合部狭窄を認めた時点 での値は対象から除外して検討した. FPLは術後著明 に低下し，尿禁制群・腹圧性尿失禁群とも術後 12 力月 の時点でも術前值より有意に短かかった $(\mathrm{p}<0.005)$. また尿失禁群の FPL 平均值は術後全経過を通じて $1.5 \mathrm{~cm}$ 末満で, 術後 12 力月の時点での腹圧性尿失禁群 
図 2 手術前後の機能的尿道長 (FPL) の推移 $[0$ 一○：尿禁制群, 缓一腹：胜尿失禁群,

完全尿失禁群, 万：mean $\pm \mathrm{SD},(\quad)$ : 症例数, * : $\mathrm{p}<0.005, *$ : $\mathrm{p}<0.01]$

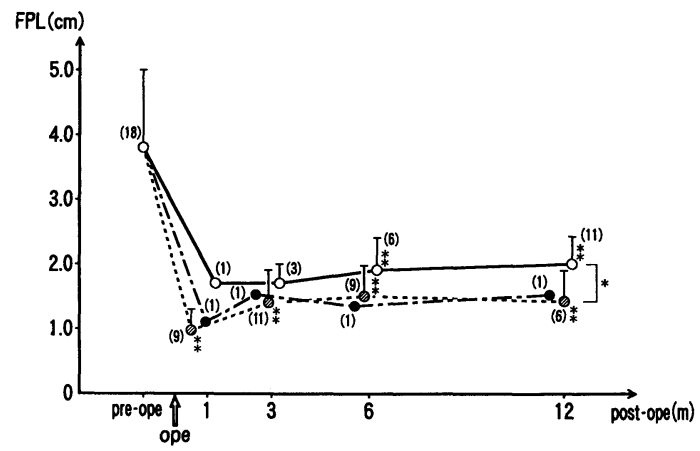

図 3 手術前後の最高尿道閉鎖圧 (UCPmax) の推移 〔○一○：尿禁制群,

的一腹圧性尿失禁群,

一：完全尿失禁群，丁：mean士 SD，（）：症例 数, *: $* 0.005, \dagger: p<0.05]$

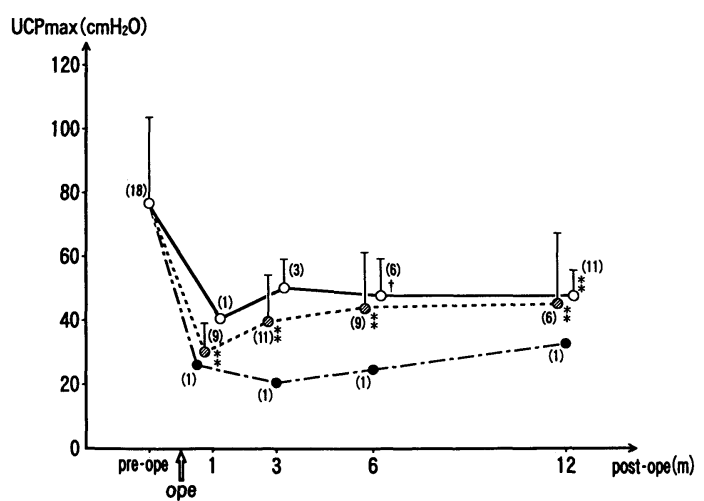

のFPLは尿禁制群の FPLに比較して有意に短か かった $(\mathrm{p}<0.01)$. UCPmax 術後著明に低下し, 術 後12力月の時点でも術前值より有意に低值であった $(\mathrm{p}<0.005)$ が，尿禁制群と腹圧性尿失禁群の UCP. max には有意差を認めなかった。 ただ，完全尿失禁症 例の UCPmax は全経過を通じて極めて低いままで あった (図 3 ).

\section{II. 術後尿失禁の検討}

根治的前立腺全摘後の尿失禁の頻度と程度を，手術 後の経過期間別に検討した（図 4 )。術後 1 力月の時点 では吻合部漏尿のためバルンカテーテルを留置した 1 例を除いた17例中16例に尿失禁を認め，しかも高度な 例が $80 \%$ 以上を占めていた。しかし高度尿失禁例の割 合は経時的に減少し，3 月月で $44 \% ， 6$ 力月以降では
図 4 前立腺全摘後の尿失禁頻度・程度の経時的推移.

$\square$ : 尿失禁なし, 軽度, 细：中等度, 口：高度

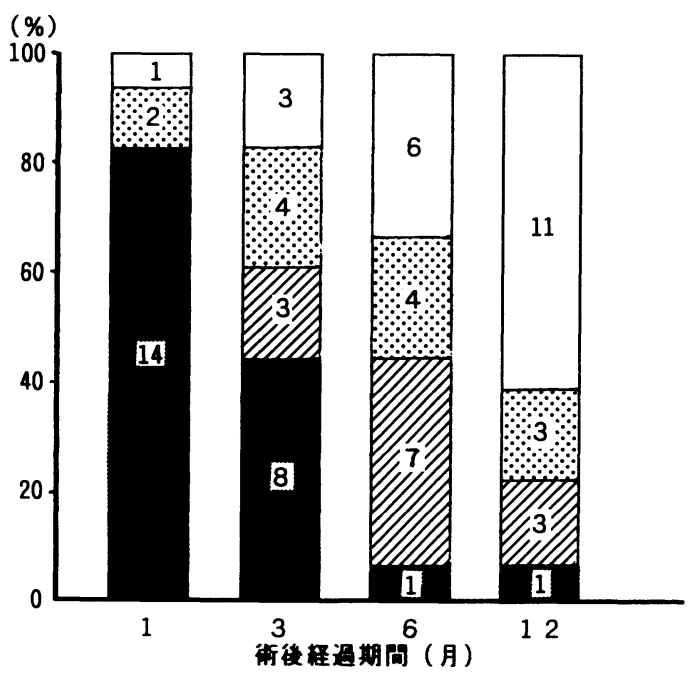

図 5 術後 12 力月での尿失禁の危険因子（1）

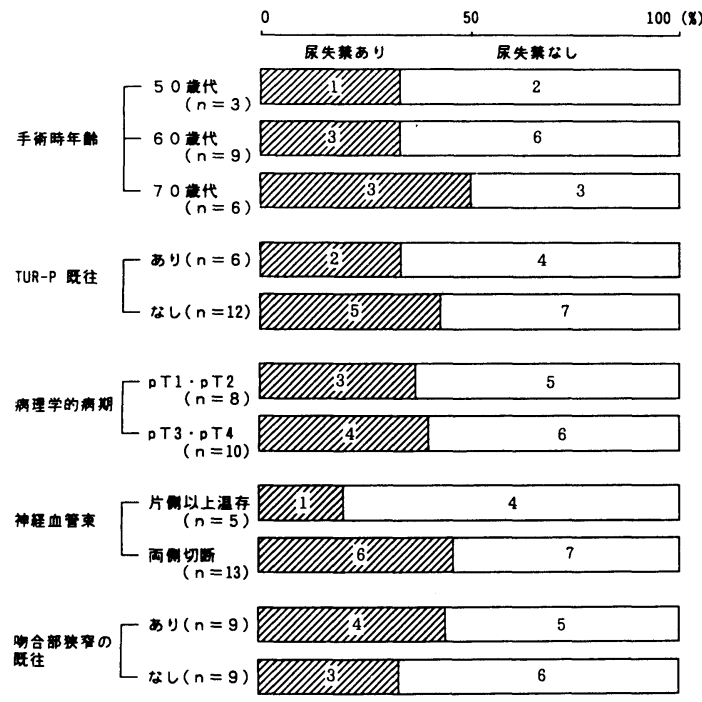

1 例（6\%）のみとなった。完全尿失禁となった 1 例 は他院で前立腺癌・臨床病期 C の診断で酢酸クロルマ ジノンを約 1 力月間内服した後に当科を初診した症例 で，右側神経血管束を温存したが膀羘頸部および後壁 の瘢痕が強く膀脱三角部左半を切除せざるを得なかっ た例であった。一方，尿禁制例は術後 3 カ月では $17 \%$ であったが 6 カ月では $33 \%, 12$ 月では $61 \%$ となった。

術後 12 月の時点での尿失禁に関与する因子につい て検討した。手術時年齢, TUR-P 既往の有無, 病理学 
図 6 術後 12 力 での尿失禁の危険因子（2）

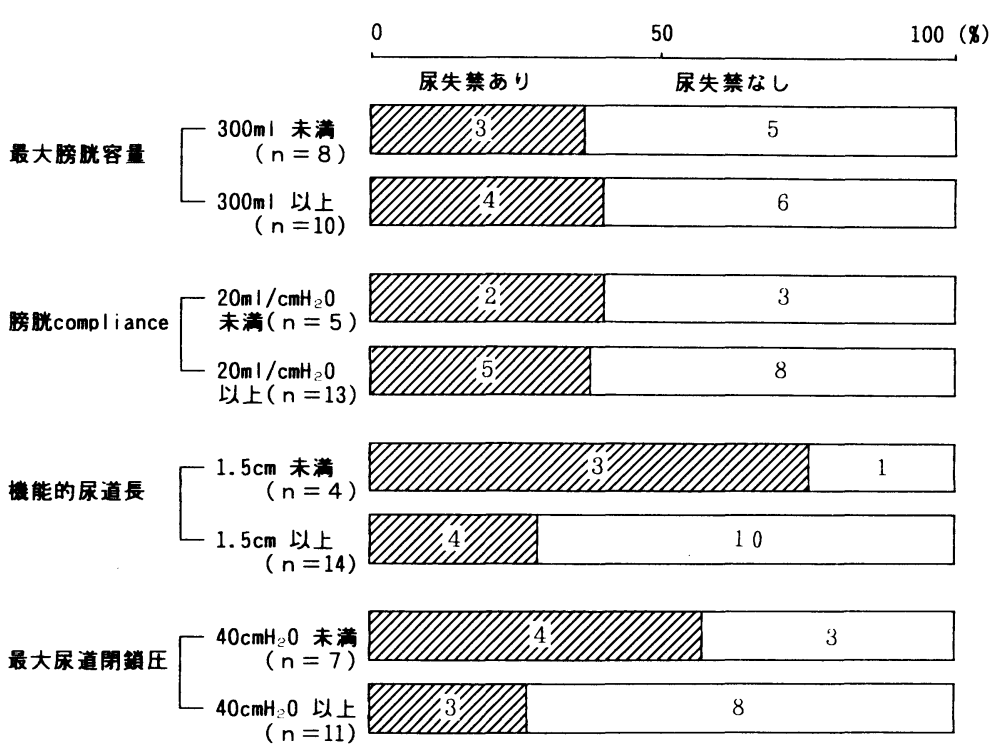

的病期，膀胱尿道吻合部狭窄既往の有無と尿失禁頻度 は関連がなかった，神経血管束を片側以上温存した例 では，両側とも切断した例と比較して尿失禁の割合が 低かったが，統計学的に有意ではなかった(図 5 ). ま た, 最大膀胼容量が $300 \mathrm{ml}$ 末満とそれ以上の例, 膀胱コ ンプライアンスが $20 \mathrm{ml} / \mathrm{cmH}_{2} \mathrm{O}$ 末満とそれ以上の例 をそれぞれ比較すると, 両者の尿失禁率には差は認め なかった。尿失禁群の FPL平均値が術後全経過を通 じて $1.5 \mathrm{~cm}$ 末満だったことより(図 2 ), FPL が $1.5 \mathrm{~cm}$ 未満とそれ以上で尿失禁率に差があるか検討した。

FPL が $1.5 \mathrm{~cm}$ 未満の例に, 尿失禁の割合が高かったが 有意差は認めなかった。 また, 尿禁制者の UCPmax 平 均値が全経過を通じて $40 \mathrm{cmH}_{2} \mathrm{O}$ 以上だったことより (図 3 ), UCPmax $か 340 \mathrm{~cm} \mathrm{H}_{2} \mathrm{O}$ 末満とそれ以上での尿 失禁率を検討した. UCPmax が $40 \mathrm{~cm} \mathrm{H}_{2} \mathrm{O}$ 末満の例に 尿失禁率が高かったが，やはり有意ではなかった（図 6 ).

\section{考察}

前立腺全摘除術後 1 カ月の UFM では, $Q \max$ の低 下や尿流曲線パターンで平坦型を呈する症例の割合が 高かった。これは膀羘尿道吻合部狭窄によるもので, 既に報告したよ5に術後早期の吻合部狭窄は比較的頻 度が高く, 早期に発見し尿道拡張ブジーを行えば狭窄 残存の確率が低いため, UFM による早期診断が極め て重要と考えられる31.

$\mathrm{CM}$ で特徴的なことは, 術後早期には低コンプライ
アンス膀胱を呈する症例が多く, 経時的に膀胱コンプ ライアンスが増大し膀脱内圧曲線パターンも正常化す る症例が多くなることであった。前立腺全摘除術後の 膀胱機能を経時的に検討した報告は少ないが，最大膀 胱容量や最大排尿笳圧には術前後に有意差はないもの の ${ }^{8) 91}$, 術後に不安定膀胼や膀胱コンプライアンスの低 下を来す例もあることが指摘されている ${ }^{910)}$. 術後早 期の膀胱コンプライアンスの低下は, 手術の影響, 特 に膀胱尿道吻合による組織の一時的硬化が関与してい るものと想定される。

UPP に打ける機能的尿道長 (FPL) と最高尿道閉鎖 圧 (UCPmax) は術後著明に低下し, 術後 12 力月の時 点でも, 両者とも術前值より有意に低值であった。 た, 術後12力月では尿失禁群の FPLは尿禁制群の FPL より有意に短縮していたが，UCPmaxには尿失 禁群と尿禁制群とで有意差は認められなかった。しか し, 完全尿失禁症例の UCPmax は術後全経過を通じ て極めて低いままであった，前立腺全摘後の尿道機能 に関しては, FPL が術後に有意に低下することは意見 が一致しているが，尿失禁例と尿禁制例とに差がある とする意見911112) と, 両者には差がないとする意見8)が ある. 一方, UCPmax についても術後に有意に低下寸 ることは意見が一致しているが, やはり尿失禁例と尿 禁制例に有意差を認める報告9)12) と有意差はないとす る報告 ${ }^{8)}$ とがある。 また, 経時的に UCPmax は高くな ることを指摘した報告8)もある。 
今回の検討では, 根治的前立腺全摘後の尿失禁の頻 度と程度は経時的に改善し, 術後 1 力月では $80 \%$ 以上 の例で高度の尿失禁を認めたが，術後12カ月では完全 尿失禁が18例中 1 例 ( $6 \%$ ), 腹圧性尿失禁が 6 例 （33\%）となり，11例（61\%）は完全に尿禁制となった。 文献的には根治的前立腺全摘後には完全尿失禁が 0 $\sim 17 \%$, 腹圧性尿失禁が $0 \sim 35 \%$ 之報告されている ${ }^{13)}$. また術後の尿失禁の頻度と程度は経時的に改善すると 言われており ${ }^{813) 14)}$, 399例での検討では 3 力月で $47 \%$, 6 力月で $75 \%, 12$ 力月で $89 \%, 2$ 年で $92 \%$ の例が尿禁 制となったと報告されている13).

今回は検討症例数が少なく確定的な事は言えない が, FPL の短縮が前立腺全摘後の尿失禁の危険因子で あり, 神経血管束の両側切断や UCPmax の低下が術 後の尿失禁に関与している可能性も示唆された。手術 時年齢, TUR-P 既往の有無, 病理学的病期, 膀脱尿道 吻合部狭窄の有無と尿失禁には関連がないものと思わ れた. 文献的にも年齢, 前立腺重量, TUR-P 既往の有 無, 病理学的病期などと尿失禁は相関しないとする報 告8)131 15) が多いが，尿失禁例の年齢は有意に高いとい 万指摘 ${ }^{16)}$ もあ。. 神経血管束温存の有無が術後の尿失 禁に関与するか否かは議論の分かれるところである。 神経血管束温存の必要性を最初に提唱したWalsh ら の593例での検討では, 両側温存例, 片側温存例, 両側 非温存例でそれぞれ $94 \% ， 92 \% ， 81 \%$ の例に尿禁制が 得られたとし, 若干の差はあるものの有意差は認めず, 神経血管束温存の有無と尿失禁とは連関しないと結論 している ${ }^{13)}$ 。その他にも神経血管束温存の有無と尿失 禁は関連がないとする報告16)17〕あるが, FPLや UCPmax は神経血管束温存群では非温存群よりも有 意に高く, 尿失禁率も低く尿禁制の回復も早いとの指 摘 ${ }^{18)}$ もある.我々は少数例の経験ではあるが, 神経血管 束温存の有無と尿失禁とは関連があるものと考学てい るが, 今後とも検討してゆく予定である。 また, 術後 1 カ月の時点で膀脱コンプライアンスが $10 \mathrm{ml} / \mathrm{cmH}_{2}$ $\mathrm{O}$ 末満と極めて低い例が $65 \%$ に認められたことより, 膀胖コンプライアンスの低下も術後早期の尿失禁に関 与しているものと想定された。一方, 今回の検討では 明らかにできなかったが, 膀胱頸部一近位部尿道の伸 展性の低下が尿失禁に最も関与すると指摘する報告 ${ }^{12}$ もある。

以上の事から，前立腺全摘後の尿失禁防止のために は，できるだけ長い尿道と膀胱頸部を残すこと，神経 血管束を温存すること，吻合部の伸展性を確保するた
めに吻合部哆開・漏尿や狭窄などを来さぬよう確実に 吻合し，吻合部やその周囲の感染を防止することなど が考兄られる218111121. また，膀胱三角部切除を余儀な くされた 1 例が術後完全尿失禁となったことより術前 に直腸診・経直腸エコー・膀胱鏡などで前立腺尖部お 上び膀胱頸部〜三角部への癌浸潤の有無を診断し, 浸 潤を認めた場合には術後の生活の質を考慮して, 他の 治療法を選択する配慮も必要と思われた。

\section{結 語}

恥骨後式前立腺全摘除術施行後 12 力月以上経過した 18例の前立腺癌症例を対象として, 膀胱・尿道機能の 変化を経時的に解析し次の結果を得た。

1）術後早期には膀脱コンプライアンスが極めて低 下する例が多いが，経時的にコンプライアンスは増大 し, 膀脱内圧曲線も正常化する例が多かった.

2) 機能的尿道長, 最高尿道閉鎖圧とも術後早期には 著明に低下し, 術後 12 力月でも術前と比較すると有意 に低值であった。

3）術後の尿失禁は, 頻度・程度とも経時的に改善す る. 術後尿失禁の危険因子としては機能的尿道長の短 縮が想定されたが, 神経血管束の両側切断や最高尿道 閉鎖圧の低下も術後尿失禁に関与している可能性も示 唆された。 また, 術後早期には膀胱コンプライアンス の低下も尿失禁に関与するものと想定された.

本論文の要旨の一部は, 第57回日本泌尿器科学会東部総 会にて発表した。

\section{文献}

1）安藤正夫：前立腺全摘除術後の尿道機能の検討. 泌尿外, 1, 315-318, 1988.

2) 安藤正夫, 寿美周平, 北原聡史, 東 四雄, 福井 㦑, 大島博幸: 前立腺全摘除術後の膀脱・尿道機能 の検討(予報). 日泌尿会誌, 79, 2012-2020, 1988.

3）安藤正夫, 森田 隆, 木原和德, 辻井俊彦, 石丸 尚, 萩原 明, 福井 㦑, 大島博幸: 前立腺全摘除 術後の膀胱尿道吻合部狭窄の検討, 泌尿外, 5 , 323-326, 1992.

4) 安藤正夫, 大島博幸: 高齢者尿失禁の病態生理学 的検討一泌尿器科外来受診者での解析. 厚生省・長 寿科学総合研究事業, 「老年者の尿失禁に関する研 究報告書」(班長。小川秋實), 5-10, 1992.

5）水尾敏之, 牛山武久, 武田裕寿, 平賀聖悟：排尿障 害に関する臨床的研究。第 2 報。尿流曲線のパター ン分類の試み.日泌尿会誌, 73, 1041-1046, 1982.

6) 安田耕作, 山西友典, 村山直人, 東 雅秀, 香村衡 一, 島崎 淳：低コンプライアンス膀胱の諸問題. 日本パラプレジフ医誌，3，48-49, 1990.

7）信野祐一郎：低コンプライアンス膀胱に関する諸 
問題．日本パラプレジア医誌，3，50-51，1990.

8) Rudy, D.C., Woodside, J.R. and Crawford, E.D. : Urodynamic evaluation of incontinence in patients undergoing modified Campbell radical retropubic prostatectomy: A prospective study. J. Urol., 132, 708-712, 1984.

9) Presti, J.C., Schmidt, R.A., Narayan, P.A., Carroll, P.R. and Tanagho, E.A.: Pathophysiology of urinary incontinence after radical prostatectomy. J. Urol., 143, 975-978, 1990.

10) Leach, G.E., Chi-Ming Yip and Donovan, B.J.: Post-prostatectomy incontinence: The influence of bladder dysfunction. J. Urol., 138, 574-578, 1987.

11) Hutch, J.A. and Fisher, R.: Continence after radical prostatectomy. Brit. J. Urol., 40, 62-67, 1968.

12) Krauss, D.J., Paletsky, S.H. and Lilien, O.M.: Urodynamics of post-radical perineal prostatectomy incontinence. J. Urol., 124, 263-265, 1980.
13) Steiner, M.S., Morton, R.A. and Walsh, P.C.: Impact of anatomical radical prostatectomy on urinary continence. J. Urol., 145, 512-515, 1991.

14) O'Donnell, P.D., Finan, B.F., Barnett, T. and Brookover, T.: Continence recovery follow. ing radical prostatectomy. Neurourol. Urodyn., 9, 251-256, 1990.

15) Lindner, A., De Kernion, J.B., Smith, R.B. and Katske, F.A.: Risk of urinary incontinence following radical prostatectomy. J. Urol., 129, 1007-1008, 1983.

16) Klein, E.A.: Early continence after radical prostatectomy. J. Urol., 148, 92-95, 1992.

17) Catalona, W.J. and Basler, J.W.: Return of erections and urinary continence following nerve sparing radical retropubic prostatectomy. J. Urol., 150, 905-907, 1993.

18) O'Donnell, P.D. and Finan, B.F.: Continence following nerve-sparing radical prostatectomy. J. Urol., 142, 1227-1229, 1989. (1993年 6 月11日受付, 1994年 3 月 8 日受理) 